\title{
Judges and \\ Religious-Based \\ Reasoning: $A$ \\ Response to \\ Ginn and Blaikie
}

\author{
Sarah E. Hamill*
}

\section{Introduction}

The Canadian jurisprudence on freedom of religion has tended to focus on the accommodation of religious practices rather than exploring the constitutionality of judicial reliance on religious-based reasoning. A recent article by Diana Ginn and David Blaikie seeks to argue that, in certain circumstances and under certain conditions, it would be acceptable for judges to rely on religious-based reasons in their judgments. ${ }^{1}$ Ginn and Blaikie see their recent article as being a continuation of sorts to their earlier piece, "Religious Discourse in the Public Square." While I found their earlier piece to be a persuasive defence of the use of religiousbased reasoning in the public sphere, I have serious doubts over the constitutionality and applicability of their argument with regard to judges. It is the purpose of this paper to refute Ginn and Blaikie's argument and to show that, in Canada, the use of religious-based reasons by judges is likely precluded by decisions of the Supreme Court of Canada.

I argue that judges, due to their role as state representatives, cannot use religiousbased reasoning in their judgments under any circumstances. I argue that in modern, secular, multicultural democracies like Canada, the state is an abstraction that at once represents all and none of its citizens. ${ }^{3}$ In the courtroom, judges represent the state and thus they must embody the abstraction of the state while acting as judges. In order for judges to represent the state, each judge must abstract him- or herself from his or her own beliefs. While I recognise that judges cannot completely abstract from their personal beliefs while acting as judges, they must be as independent and as neutral as possible when acting in their judicial capacity. I argue that in Canada, freedom of religion means accommodation, not support, and express judicial reliance on religious-based reasoning would be support and thus violate section 2(a) of the Charter of Rights and Freedoms. ${ }^{4}$

I begin with an exploration of the development of secularism and its importance to the freedom of religion more broadly. I then move on to explore the development of freedom of religion jurisprudence in Canada. I argue that the jurisprudence shows that freedom of religion is understood as being accommodation of and not support of religions and religious practices. I then move on to apply the jurisprudence to the possibility of judicial reliance on religiousbased reasoning and, where necessary, I directly engage with Ginn and Blaikie's argument. I argue that Ginn and Blaikie fail to apply the relevant jurisprudence and fail to provide a convincing argument in defence of judicial use of religious-based reasoning. I conclude that Supreme Court jurisprudence has likely precluded judges' use of religious-based reasons under any circumstances. 


\section{The context, development and meaning of freedom of religion}

\section{The development of secular states}

The notion of secularism in modern Western democracies stems from the European Reformation and is usually understood to mean the separation of church and state..$^{5}$ The spilt of the Western Church during the Reformation was traumatic, and unleashed violence across Western Europe as both sides engaged in bloody struggles in their efforts to dominate one another. Religion became intertwined with national identity; tolerance of religious minorities was rare and usually depended on the religious minorities keeping their dissent hidden, thus restricting their ability to seek new converts or political power. ${ }^{6}$ However, with the emergence of Western democratic states a degree of religious tolerance appeared and increased as religious power and political power became further separated. Pierre Manent argues that the modern democratic state was constructed to "overcome religious differences," state and its political institutions as "power that is without opinion." Manent argues that although the idea of this power was articulated in the seventeenth century, it was only turned into actual institutions in the nineteenth and twentieth centuries. ${ }^{8}$ The liberty that these Western democracies provide to their citizens is founded on "an organisation of separations." The separation of church and state is an example of a separation instituted for the sake of liberty and, as a consequence, religion is removed from the public sphere: "The public forum is more and emptier so that we can be more and freer."10

Arguably, this empty public sphere is more workable within a Christian context than within other religious contexts-especially religions like Islam or Judaism, which have a religious law that contains political laws as well and makes no distinctions between the secular and the religious spheres. ${ }^{11}$ With the increasing prevalence of multiculturalism, the traditions that helped create a secular sphere that is cut off from the religious appear to make less and less sense because they are less and less familiar to a significant number of citizens living in these states. Rather than making secularism less important to ensuring religious freedom, increased and increasing multiculturalism requires a new understanding of secularism, one that understands 'secular' as meaning neutrality towards religious views rather than the absence of religious views in the public sphere. ${ }^{12}$ This new understanding protects the use of religious reasons in the public sphere, while preventing the state or its representatives from preferring one religion over another. ${ }^{13}$

Understanding 'secular' as describing a society that does not give preference to any one religion, rather than being a society without religion, leaves space for religion in the public sphere. It would also be in keeping with democratic principles that are key tenets of the modern secular state. If "[d]emocracy makes all relations and all bonds voluntary,"14 a secular state which treats all religions equally by not preferring or restricting one over the rest, would be allowing the freedom of religion that is implied in such an understanding of secularism.

The result of this understanding of secular as neutrality between religions but not the complete absence of religion is that the state will not be an exact reflection of each citizen, because the state will not enforce religious norms. As Manent succinctly puts it "living at once in both civil society and the state, I am never quite whole anywhere."15 Arguably, though, the individual is never completely divided either. Even if the good citizen abstracts from his religion, as Manent argues he or she must to be a good citizen, ${ }^{16}$ she or he will never be able to abstract from it completely. Believers may remove religious symbols and refrain from proselytising, but they will still be believers, and will still hold the values of their religion and it will still influence and inform how they act. The modern secular democratic state does not mirror specific individuals, nor does it represent an average of its citizens' lifestyles and opinions, nor does it pick and choose aspects of its citizens' lifestyles and opinions; such representations would be an absurdity. Rather, the state represents all of its citizens and none of 
them because it is abstracted from them.

To summarise then, freedom of religion and secularism are intertwined in many Western democracies, ${ }^{17}$ and because of this, religious freedom manifests itself in two interlinked phenomena: first, the state is power without opinion; and second, that freedom exists as separation, both of state power and religious power, and citizens and believers. I will now move on to show that these two phenomena are found in Canadian freedom of religion jurisprudence and that they are particularly applicable to state actors.

\section{Freedom of religion in Canada}

When discussing the evolution of freedom of religion in Canada, the starting point is usually, $R v$ Big M Drug Mart. ${ }^{18}$ This case dealt with the constitutionality of Sunday closing legislation. The Supreme Court found that the Lord's Day Act had a religious purpose and thus violated section 2(a) of the Charter. ${ }^{19}$ In other words, if a piece of legislation is found to have an offensive purpose, such as forcing the observation of the Christian Sabbath, the legislation cannot be saved by permissible effect, such as a mandatory day of rest for workers. The Court stated that "a truly free society is one which can accommodate a wide variety of beliefs." 20 In other words, freedom of religion is the accommodation of religious beliefs and not state support of particular religious practices through legislation or other means. Sunday closing legislation supported Christianity and as a consequence failed to accommodate other religious practices. ${ }^{21}$ The Court's decision also served to uphold religious freedom by separating religious power from state power. Big M Drug Mart served to separate the Christian from the citizen because good citizens no longer had to follow a Christian model such as using Sunday as their day of rest. This separation of believer and citizen is equally true for all who practice a religion because the state no longer privileges one religion over another. ${ }^{22}$

The Court did not explicitly discuss judicial use of religious-based reasons, but a close reading of the case suggests that Big M
Drug Mart would not support a judge's use of religious-based reasons. If we extend the permissible effect finding to a judge's use of religious reasons, it is likely that, following Big $M$ Drug Mart, these religious-based reasons would be found to have an offensive purpose. Dickson J, writing for the majority, described Sunday closing legislation as taking "religious values rooted in Christian morality and, using the force of the state, translat[ing] them into a positive law binding on believers and nonbelievers alike." 23 Judges, when they perform their judicial duties, represent the state and thus whatever judges say as judges is taken to be a declaration of the state's views on a matter. Therefore, judges are not free to use their own views, whether political or religious, to help them decide a case.

In a more recent case, Syndicat Northcrest $v$ Amselem,$^{24}$ the Supreme Court stated that it would not involve itself in theology: "Secular judicial determinations of theological or religious disputes, or of contentious matters of religious doctrine, unjustifiably entangle the court in the affairs of religion." 25 Here the Supreme Court clearly states that it sees itself as a secular institution, separate from religion, which has no reason, no right, to pronounce on questions of theology. Arguably, this statement would also preclude judges from using religious-based reasons in their judgments because a judge's religious-based reasons would privilege his or her understanding of religion and thus it would stray into issues of theology. Amselem also reinforces the separation between religious power and state power through its delineation of what each power has the right to decide: religious power can decide questions of theology; state power can decide questions of religious accommodation.

The Court had defined 'secular' two years before it decided Amselem, in the case of Chamberlain. Chamberlain dealt with whether or not a school board could exclude books on same-sex parenting from being used in the classroom. ${ }^{26}$ In its decision the Court discussed the meaning of 'secular' and held that it meant religious neutrality, not the absence of religion. ${ }^{27}$ The decision in Chamberlain shows that 'secular' 
means accommodation of and abstraction from religion: for it allows different religious views to be heard but it separates itself from them by not privileging one over the other.

The Court found that the Surrey school board in Chamberlain was not like a legislature or council because it lacked autonomy. ${ }^{28}$ The Court did not describe the school board as a court either, ${ }^{29}$ but it did outline what the requirements of secularism were and, given the Court's selfdeclared secular nature in Amselem, it is hard to avoid the conclusion that the requirements of "strict secularism" will likely apply to Canadian courts as well. The Court said that secularism required respect of "the views of all members of the community," that no view of one community could be preferred over the view of other segments of the community, and that all lawful lifestyles are recognised as equally valid. ${ }^{30}$ The Court also repeatedly stated that secularism required the promotion of tolerance and respect for all views. ${ }^{31}$ It is hard to see how a judge using religious-based reasons could avoid preferring one religious viewpoint over another.

In their article, "Judges and ReligiousBased Reasoning," Ginn and Blaikie try to argue that there are certain occasions when it would be acceptable for judges to use religiousbased reasoning. In the next section I move on to show that their attempt to allow for religiousbased reasons- even in very restricted circumstances-would be unconstitutional because it would automatically violate section 2(a) of the Charter as well as violate previous judicial pronouncements from the Supreme Court.

\section{The unconstitutionality of judges' religious-based reasons}

Ginn and Blaikie do not argue that judges can use religious-based reasons whenever they see fit; rather, they argue that religious-based reasons can only be used by judges in cases of "legal underdeterminancy." 32 Their definition and examples of "legal underdeterminancy" are less than convincing and are occasionally in danger of being unintentionally offensive. Ginn and Blaikie define "legal underdeteminancy" as when "the relevant constitutional principles, legislation and case law do not resolve the issue, and where substantial interpretation and development of the law is required in order to decide the matter before the judge." ${ }^{33}$ They add the requirement that "the reasoning must conform to the constitutional requirement that the state remain neutral as among different religions and as between religion and non-religion." ${ }^{34}$ I find it hard to see how religious-based reasoning could conform to the requirement of neutrality, but Ginn and Blaikie provide one example of a judgment which they think used religiousbased reasoning and then go on to provide two examples of cases where their understanding of religious-based reasoning might have been acceptable.

Ginn and Blaikie attempt to provide an example of religious-based reasoning in a case of legal underdeterminancy by quoting Lord Atkin in Donoghue $v$ Stevenson. ${ }^{35}$ Lord Atkin made reference to the parable of the Good Samaritan to explain his "neighbour" principle:

\begin{abstract}
The rule that you are to love your neighbour becomes in law you must not injure your neighbour; and the lawyer's question, "Who is my neighbour?" receives a restricted reply. You must take reasonable care to avoid acts or omissions which you can reasonably foresee would be likely to injure your neighbour. Who, then, in law, is my neighbour? The answer seems to be-persons who are so closely and directly affected by my act that I ought to reasonably have them in contemplation as being so affected when I am directing my mind to the acts or omissions which are called in question. ${ }^{36}$
\end{abstract}

Given that Donoghue was decided in 1932, and in a country which still does not describe itself as secular, ${ }^{37} \mathrm{I}$ am doubtful that Lord Atkin was consciously engaging in religious reasoning. There is no mention of religion, Jesus, the Bible or Christianity in the judgment. I would describe Lord Atkin's use of the Good Samaritan parable as 'cultural shorthand' rather than religiousbased reasoning. Most people in the UK at the time would have shared the moral values of Christianity and thus Atkin's “neighbour principle" was arguably the imposition of shared democratic values rather than the use of 
a specifically religious value.

The first case that Ginn and Blaikie use to illustrate the potential acceptability of religiousbased reasons is Dobson (Litigation Guardian of) $v$ Dobson..$^{38}$ The issue in Dobson was whether or not a child could sue his mother for harms caused by her negligence during pregnancy. Mrs Dobson, while six months pregnant, crashed her car crash and her son, Ryan, suffered prenatal injuries, was born prematurely and was severely disabled as a result of the prenatal injuries he suffered. Ryan then launched a tort claim against his mother for her alleged negligent driving. ${ }^{39}$ Ginn and Blaikie argue that while there was some related case law, there was nothing directly on point and because the Supreme Court had to make a decision over which competing public policy alternatives should prevail, the law was underdetermined and therefore it would have been acceptable for the Court to engage in religious-based reasoning. ${ }^{40}$

Ginn and Blaikie present a hypothetical alternate to the judicial history of Dobson in order to argue that religious-based reasoning would be constitutional. They invent a hypothetical lower court judge who has to balance the autonomy of a pregnant woman against the harm done to the child, an issue which was yet to be resolved at the time Dobson was decided.

In deciding that concerns for the mother's autonomy outweighed other arguments, Ginn and Blaikie's hypothetical judge might refer explicitly to her belief that God created men and women equal. Since individual autonomy is a core value of Canada's legal system, on appeal Ryan Dobson would have had to argue that women's autonomy would not be undermined by allowing a child in his situation to sue, or that autonomy for the pregnant woman is outweighed by other equally core values. He would not have had to persuade the appeal court that the lower court judge was wrong in her conviction that God created men and women equal. ${ }^{41}$

The question that Ginn and Blaikie do not answer is why the judge would need to refer to religious reasons when Canada's Constitution already holds that men and women are equal. ${ }^{42}$ Surely if the lower court judge relied on religious reasons rather than the core value of gender equality, which is enshrined in the Charter, this lower court judge would be held to have erred in law?

Ginn and Blaikie's hypothetical lower court judge would also have violated the guidelines hinted at in current Supreme Court jurisprudence, which prevent law from imposing a specific religious purpose. Ginn and Blaikie try to argue that a judge using religious-based reasons as a starting point would not be a case of the state acting for a religious purpose and that "the state would not have set one religion above another, nor would it have privileged religion above atheism or agnosticism." ${ }^{33}$ I respectfully disagree because a judge using religious-based reasons, even as a starting point, is effectively saying that the democratically agreed upon and secular (in a Chamberlain sense) core values are not guidance enough, are not convincing enough. Moreover, the judge in using religiousbased reasons would be acting as a citizen and not as a judge who is an abstracted representative of the state. Judges have a duty to abstract themselves as far as possible from their personal views and to apply only the law and values of the state in their judgments. ${ }^{44}$

Dobson is a poor choice to advance an argument about religious-based reasoning simply because most of the world's major organized religions explicitly prohibit abortion and deny that a pregnant woman has autonomy over her own body. ${ }^{45}$ Mothers have been blamed by both society and scientists for a host of 'problems' in their offspring, ranging from autism, homosexuality, schizophrenia, bed-wetting, drug use, and "homicidal transsexualism." 46 Thus Dobson, with its failed attempt to extend a duty of care upon a pregnant woman towards her foetus, has ugly echoes of maternal blame and denials of a woman's right to bodily determination. The Supreme Court found that the imposition of tort liability on pregnant women for damage suffered by the foetus "would significantly undermine the privacy and autonomy rights of women" and thus found that Mrs Dobson 
was not liable in tort for the injuries Ryan suffered. ${ }^{47}$ Ginn and Blaikie defend their choice of Dobson by claiming that the secular arguments advanced in the case would have been just as "hotly contested" as any religiousbased reasons. ${ }^{48}$ While I agree that not everyone would find the secular reasoning of the Court in Dobson convincing, that does not support the conclusion that lack of agreement would justify religious-based reasons. In Dobson, the Supreme Court represented the state and thus it had a duty to be neutral when applying the law. The controversy over the issues at stake in Dobson was all the more reason for the Court to provide a judgment that was tied to democratically predetermined core values in the Canadian legal system. Veit Bader has argued that "liberal democracy cannot be neutral" 49 and while I would agree with him, ${ }^{50}$ the important point is that liberal democracies allow for all views to be heard, but not imposed. When courts issue judgments they are imposing views that, ideally, have already been decided in the public sphere through democratic processes. The controversy in Dobson stemmed from Canadian society's view of women, motherhood, and appropriate behaviours during pregnancy and should not have been used to attempt to justify the constitutionality of religious-based reasoning.

I am not convinced that Dobson was actually a case of legal underdeterminancy because the Supreme Court was able to decide the case and could rely on core values in the Canadian legal system to do so. A better example of legal underdeterminancy would have been the United Kingdom case of Re A (Children) (Conjoined Twins: Surgical Separation). ${ }^{51}$ This case involved conjoined twin girls, Jodie and Mary, who would both die if they were not surgically separated; however, if they were surgically separated, Mary would die automatically and thus give Jodie a chance at life. The girls' parents had refused permission for the surgical separation to go ahead because it violated their Christian beliefs. Ward LJ said "that [independent and objective] judgment is the law. That is what I am desperately trying to do." 52 The Court of Appeal had no legislation to apply, no legal precedent to invoke and follow, so how could any decision be justified? Given that the conflicting rights in this case were the same, namely each twin's right to life, the balancing act that the Court had to attempt was much more difficult, for any attempt to uphold one twin's right to life automatically stripped the other twin of her right to life.

Ginn and Blaikie do not mention the Conjoined Twins case but they do concede that their argument is more challenging when religious belief plays some part in the dispute itself, and they use the example of Brockie $v$ Brillinger to illustrate their point. ${ }^{53}$ This case dealt with Mr Brillinger's human rights complaint against $\mathrm{Mr}$ Brockie, the owner of a printing company who refused to print materials for the Canadian Lesbian and Gay Archives because Brockie's religious beliefs held that homosexuality was a sin. Brillinger's human rights complaint was upheld, but Ginn and Blaikie present a hypothetical court appeal to argue that Canadian law does not provide proper guidance on how to resolve situations when rights conflict with each other. ${ }^{54}$ Ginn and Blaikie attempt to argue that any judge in such cases of conflicting rights would have to turn to a set of extra-judicial values and that these values might still be constitutional if they were religious in nature. ${ }^{55}$ In this hypothetical case, Ginn and Blaikie find that religious-based reasons could conflict with the constitutional requirement of neutrality, ${ }^{56}$ though they argue that the unconstitutionality of the religiousbased reasons depends on their wording, rather than the fact that they are religious-based reasons. While it is true that Canadian law does not provide much guidance on how to resolve competing rights' claims, the jurisprudence on freedom of religion upholds and encourages accommodation of religious beliefs and practices but does not support the imposition of these religious beliefs and practices on others. Had the human rights adjudicator decided in favour of Brockie, she would have supported his right to impose his religious belief that homosexuals are unworthy of equality. The adjudicator did not require Brockie to change his religious belief; she required him to practice his religion in a way that did not contravene Canada's core values of equality and respect for everyone. ${ }^{57}$ 
In their conclusion, Ginn and Blaikie argue that it is not possible for anyone to "bracket" their fundamental beliefs when making certain sorts of decisions. ${ }^{58}$ While I would agree that it is impossible for judges to abstract themselves from their religious beliefs completely, that does not mean that they can rely on them when they are acting for the state in their judicial capacity. ${ }^{59}$ Ginn and Blaikie recognise that "the use of such [religious-based] reasoning by judges does raise questions about the role of judges, fairness, and constitutionality, which must be taken seriously" 60 but their proposed safeguards ${ }^{61}$ would not prevent religious-based reasoning from violating the Constitution. I would argue that, given current Canadian Supreme Court jurisprudence, any reliance on religious-based reasons by judges is automatically precluded.

\section{Conclusion}

I have argued that there is no circumstance when it would be acceptable for Canadian judges to use religious-based reasons in the decision-making process. Canadian Supreme Court jurisprudence strongly suggests that freedom of religion means accommodation of religion not support of religion. ${ }^{62}$ Consequently, a judge who used religious-based reasons in his or her judgment would automatically violate section 2(a) of the Charter because the judge, acting as a representative of the state, would be supporting a particular religion through his or her use of religious-based reasons. In addition, the judge would also be violating the secular nature of Canadian courts, which requires that no preference is given to any one religion. The proper procedure for judges to follow is to apply the core values of the state, which have been arrived at following democratic dialogue. The democratic dialogue from which the state's core values emerge is the appropriate forum for using religious-based reasoning. ${ }^{63}$ Therefore, judges may not invent such core values by themselves; ${ }^{64}$ they have to apply the core values of the state, and not their own personal core values, whether religious or otherwise.

\section{Notes}

* $\quad \mathrm{PhD}$ Candidate, Faculty of Law, University of Alberta.

1 Diana Ginn \& David Blaikie, "Judges and Religious-Based Reasoning” (2011) 19:2 Const Forum Const 53 [Ginn \& Blaikie, "Judges"].

2 Ibid at 53; David Blaikie \& Diana Ginn, "Religious Discourse in the Public Square" (2006) 15:1 Const Forum Const 37 [Blaikie \& Ginn, "Religious Discourse"].

3 Pierre Manent, A World Beyond Politics? A Defense of the Nation State (Princeton: Princeton University Press, 2006) at 29 [Manent].

4 Canadian Charter of Rights and Freedoms, Part I of the Constitution Act, 1982, being Schedule B to the Canada Act 1982 (UK), 1982, c 11, s 2(a) [Charter].

5 Manent, supra n 3 at 26-28; TN Madan, "Secularism in Its Place" in Rajeev Bhargava, ed, Secularism and Its Critics (New Dehli: Oxford University Press, 1998) 297 at 307 [Madan]. Arguably, the division of Church and state was first mentioned in the New Testament with Jesus' comment to render "unto Caesar what is Caesar's and unto God what is God's" at Matthew 22:21. It was not until the Reformation that this division began to emerge within European states.

6 For example, in 1527 Basle allowed everyone to follow their own conscience provided there was no open articulation of dissent. See Hans R Guggisberg, "Tolerance and Intolerance in Sixteenth Century Basle" in Ole Peter Grell \& Bob Scribner, eds, Tolerance and Intolerance in the European Reformation (Cambridge: Cambridge University Press, 1996) 145 at 146, 149. See also, Sally L Jenkinson, "The Public Context of Heresy: Bayle, Maimbourg and Le Clerc" in John Christian Laursen, ed, Histories of Heresy in Early Modern Europe: For, Against and Beyond Persecution and Tolerance (New York: Palgrave Macmillan, 2002) 119 at 124.

7 Manent, supra n 3 at 27-28.

$8 \quad$ Ibid at 27-28.

$9 \quad$ Ibid at 13 .

$10 \quad$ Ibid at 9.

11 Ibid at 26. It should be noted that many, if not all, religions have something to say about how their adherents should live in the wider community. See Richard Moon, "Religious Commitment and Identity: Syndicat Northcrest v Amselem" (2005) 29 Sup Ct L Rev (2d) 201 at 219.

12 Chamberlain $v$ Surrey School District No 36, 2002 SCC 86 at paras 18-25, [2002] 4 SCR 710 [Chamberlain]; Iain T Benson \& Brad 
Miller, "Court Misunderstands the Meaning of "Secular"': Chamberlain v Surrey School District No. 36, online: (1999) LexView 25.0, Cardus.ca $<$ http://www.cardus.ca/lexview/ article/2340/>. This article refers to the trial judgment, Chamberlain v Surrey School District No. 36, [1998] BCJ No 2923. There is some debate as to the correct and historical meaning of "secular". See Benjamin Berger, "The Limits of Belief: Freedom of Religion, Secularism, and the Liberal State" (2002) 17 CJLS 39 at 49-51 [Berger, "Limits of Belief"]; Iain T Benson, "Considering Secularism" in Douglas Farrow, ed, Recognizing Religion in a Secular Society: Essays in Pluralism, Religion, and Public Policy (Montreal: McGill University Press, 2004) 83 at 85, 90 [Benson, "Considering Secularism"]; Iain T Benson, "Notes Towards a (Re) Definition of the "Secular"" (1999-2000) 33 UBC L Rev 519 [Benson, "(Re) Definition of the 'Secular"]. Regardless of whether the Supreme Court got the historical definition of "secular" correct, I would argue that they got the definition correct in the context of a modern, multicultural state such as Canada.

13 I would argue against John Rawls's requirement that citizens translate religious reasons into secular reasons in order for these reasons to be acceptable in the public sphere. Rawls outlined the requirement of "public reasons" in Political Liberalism (New York: Columbia University Press, 2005) 3rd ed, at 216-217 [Rawls]. Rawls's "public reasons" have been critiqued extensively. See Richard W Bauman \& Sarah LM Weingarten, "Keeping Religious Fundamentalism Under Wraps: The Clothing Controversy in Selected European Countries" (2006) 15:1 Const Forum Const 1 at 13 [Bauman \& Weingarten]; Blaikie \& Ginn, "Religious Discourse", supran 2 at 40-41, 49-50; Veit Bader, "Religious Pluralism: Secularism or Priority for Democracy?” (1999) 27 Political Theory 597 at 599 [Bader]; Berger, "Limits of Belief", supra n 12 at 43-44; Jonathan Chaplin, "Beyond Liberal Restraint: Defending Religiously-Based Arguments in Law and Public Policy" (1999-2000) 33 UBC L Rev 617 [Chaplin]. This is not an exhaustive list.

14 Manent, supra $\mathrm{n} 3$ at 115.

$15 \quad$ Ibid at 29.

$16 \quad$ Ibid at 28.

17 But not all. A recent case from the United Kingdom denied that the country was secular, but argued that religious freedom still existed. See $R$ (on the application of SB) $v$ Governors of Denbigh High School, [2006] UKHL 15 at paras
61-62, [2006] 2 All ER 487 [Denbigh]. For more on this case see, Bauman \& Weingarten, supra $\mathrm{n}$ 13 at 7-9; Anastasis Vakulenko, "Islamic Dress in Human Rights Jurisprudence: A Critique of Current Trends" (2007) 7 Human Rights Law Review 717. It should also be noted that England still has an established church but that Scotland, Wales and Northern Ireland do not; therefore it would be incorrect to say that the UK still has an established church.

18 [1985] 1 SCR 295, 1985 CanLII 69 (SCC) [Big M Drug Mart].

19 Ibid at paras 78-93, 130, 150.

$20 \quad$ Ibid at para 94.

21 The importance of the idea of accommodation has been found in many other cases dealing with freedom of religion. See e.g. Multani v Commission Scolaire Marguerite-Bourgeoys, 2006 SCC 6, [2006] 1 SCR 256; Rosenberg v Outremont (City), [2001] RQJ 1556.

22 As mentioned above, many of the core values now considered secular had a religious origin, thus the separation between believer and citizen is not always clear-cut.

23 Big M Drug Mart, supra n 18 at para 97.

242004 SCC 47, [2004] 2 SCR 551 [Amselem].

25 Ibid at para 50.

26 Chamberlain, supra $\mathrm{n} 12$ at para 1.

27 Ibid at paras 18-15. This requirement of secularism was imposed on the school board by the School Act, RSBC 1996, c 412, preamble, s 76. Benjamin Berger has convincingly argued that this understanding of "secular" has a long history in Canadian jurisprudence and that it protects a place in civil society for religious-based debate. However, Berger makes no mention of the acceptability of judicial use of religious-based reasons. See Berger, "Limits of Belief", supra n 12

28 Chamberlain, supra n 13 at para 28.

29 Technically, Chamberlain was decided on administrative law grounds and the violation that the Court found was of the School Act and not the Charter.

30 Chamberlain, supra $\mathrm{n} 12$ at paras 25, 27.

31 Ibid at paras 25, 28, 33.

32 Ginn \& Blaikie, "Judges", supra n 1 at 53-54.

33 Ibid at 53.

34 Ibid.

35 [1932] UKHL 100, [1932] AC 562 (BaiLII) [Donoghue].

36 Ibid at 580.

37 See Denbigh, supran 17 at paras 61-62. Donoghue was a Scottish case and Scotland is not thought to have an established church, but House of Lords judges were not always overly 
sensitive to the subtle differences between the UK's constituent nations.

[Dobson].

39 Ibid at paras 1-4.

40 Ginn \& Blaikie, "Judges", supra $\mathrm{n} 1$ at 54.

$41 \quad$ Ibid at 57.

42 Charter, supra n 4at ss 15, 28.

43 Ginn \& Blaikie, "Judges", supra n 1 at 59.

44 This requirement of abstraction means that judges must also abstract themselves from their political views.

45 For example, the Irish Constitution enshrines the right of the unborn which serves as an extra safeguard against abortion, Constitution of Ireland, 1937, art 40.3.3. Abortion remains illegal in Ireland under the Offences Against the Persons Act, 1861, 24 \& 25, Vict c 100, ss 28-29. Interestingly, these sections are still in force in Northern Ireland, thus abortion is illegal in Northern Ireland but legal in the rest of the United Kingdom. The European Court of Human Rights [ECtHR] recently ruled that there was no right for women to access abortion but that Ireland had violated the Convention on Human Rights by failing to provide a safe and effective procedure by which a woman can discover whether she qualifies for a legal abortion under current Irish law. See $A, B$ and $C v$ Ireland, [2010] ECHR 2032. The ECtHR made no mention of Northern Ireland in its judgment.

46 Anita Ilta Garey \& Terry Arendell, "Children, Work and Family: Some Thoughts on "Mother Blame”, Rosanna Hertz \& Nancy L Marshall, eds, Working Families: The Transformation of the American Home (Berkeley: University of California Press, 2001) 293-294.

47 Dobson, supra n 38 at para 44. The Court went on to argue that such an imposition would damage the future relationship between mother and child, at para 46. Arguably, much of the judgment in Dobson contained troubling views of the role of mothers, but a full critique of the case is beyond the scope of this paper. Suffice it to say that the Court reached the right decision even though much of the obiter dicta had a troubling conception of pregnant women.

48 Ginn \& Blaikie, "Judges", supra n 1 at 58.

49 Bader, supra n 13at 613.

50 Liberal democracies will have to impose the views that result from their democratic processes, therefore accommodation of minorities and religious beliefs will necessarily be tempered by the need to uphold the core values of the liberal democracy in question.
51 [2000] 4 All ER 961 [Conjoined Twins].

52 Ibid at 1008, cited in Scott Veitch, "'A Very Unique Case': Reflections on Neil MacCormick's Theory of Universalization in Practical Reasoning" in Zenon Bankowski \& James MacLean, eds, The Universal and the Particular in Legal Reasoning (Aldershot: Ashgate, 2006) 143 at 147. Each of the three appeal judges gave very different reasons for their decision that the separation could go ahead: one invoked self-defence, one invoked necessity, and one relied on the intention of the surgeons because the surgeons as doctors necessarily lacked the necessary mens rea for murder.

53 Brockie v Brillinger (No 2) (1999), 37 CHRRD/12 (Ont Bd Inq) [Brockie]; Ginn \& Blaikie, "Judges", supran 1 at 59 .

54 The rights at stake in Brockie were the right to religious freedom and the right not to be discriminated against. See Ginn \& Blaikie, "Judges", supra n 1 at 59-60.

55 Ibid at 60.

56 Ibid.

57 The Supreme Court of Canada has expressly upheld equality as being a core Canadian value in Bruker v Marcovitz, 2007 SCC 54, [2007] 3 SCR 607.

58 Ginn \& Blaikie, "Judges", supran 1 at 60-61.

59 Here I would agree up to a point with Gerard Bouchard and Charles Taylor's conclusion that police officers and judges ought to appear neutral, as set out in Building the Future: A Time for Reconciliation, online: <http://www. accommodements.qc.ca/documentation/ rapports/rapport-final-integral-en.pdf $>$ at 142-43. Bouchard and Taylor argue that this requirement of neutrality would mean that judges and police officers could not even wear religious symbols while doing their job. I would argue that it is acceptable for all government employees to wear religious symbols or clothing while working, as long as they remain neutral when exercising their duties.

60 Ginn \& Blaikie, "Judges", supra n 1 at 61.

61 These safeguards are that such reasoning can only take place in instances of legal underdeterminacy and that actual reasoning and analysis must occur, ibid at 60-61.

62 This view is echoed in Carissima Mathen, "What Religious Freedom Jurisprudence Reveals About Equality" (2009) 6:2 JL \& Equality 163 at 179, 193.

63 Thus I would argue against Rawls, supra n 13.

64 It should be noted that judges do sometimes attempt to invent core values. For a discussion 
and critique of this, see Alex Schwartz, "The Rule of Unwritten Law: A Cautious Critique of Charkaoui v Canada" (2008) 13:2 Rev Const Stud 179. ${ }^{\text {I }}$ 
